\title{
The rules of international jurisdiction in Spanish law
}

\author{
Enrique PECOURT GARCÍA*
}

\section{INTRODUCTION}

I. The statutory distinction between laws ad ordinandam litem and rules ad decidendam litem is often cited as a doctrinal precedent of so-called "conflicts of jurisdiction". This reference could mistakenly lead one to believe that conflicts of laws and conflicts of jurisdiction have a common doctrinal origin and have developed in parallel. Obviously, this has not been the case: "on a étudié pendant des siècles les conflits de lois sans reprendre parallèlement l'étude de la compétence judiciaire". Today, however, the intense attention given in the scholarly literature to what is also known as "international procedural law", ${ }^{2}$ due to both its substantive importance and the increasingly obvious interconnection

(1937-1997). Former Professor of International Law, Universitat de València. This work was previously published in Spanish as "Las normas de competencia judicial internacional en el Derecho español", in 2 Anuario del Instituto HispanoLuso-Americano de Derecho internacional (1963), 195-208.

Ed.: As in previous cases in this same section, we have tried to adapt the original format of this contribution to the the format normally used in SYbIL.

I H. Batiffol, "Observations sur les liens de la compétence judiciaire et de la compétence législative", in De Conflictu Legum: Essays presented to R. D. Kollewijn and J. Offerbaus (Sijthoff, Leiden, 1962), at 66.

In the most generic sense, this subject comprises the set of issues involved at the procedural level in the domestic legal regulation of so-called private international relations or situations (also called "multinational" or "extranational relations" or "private international transactions"). The subject still lacks a clear substantive delimitation in the general scheme of legal disciplines. This is mainly due to the disparities in the scholarly works offering conceptual and systematic descriptions of it. Whilst a detailed analysis of the terms in which the subject is approached in the literature falls beyond the scope of this essay, it should be recalled that the core question consists in determining the interdisciplinary relations between private international law sensu stricto, primarily made up of conflicts of laws, and the subject at hand. For one school of thought, the latter is a fully integrated part of private international law, constituting a primordial dimension thereof (Anglo-Saxon conceptions) or one of its special parts (the thesis generally held in French doctrine and defended in Spain by Trías de Bés, Miaja de la Muela and Aguilar Navarro, amongst others), whereas for another it is a separate discipline (Italian and German doctrine) or a substantive chapter of "external state law" or "state law concerning external relations" (Von Bar, Morelli). Other particularly nuanced conceptions frame it as "procedural law for foreign nationals" (Goldschmidt) or, more recently, "procedural assistance law" combined with rules of domestic law referring to the involvement of foreign nationals in the process (Cf. N. Alcalá-Zamora, "Bases para unificar la cooperación internacional procesal”, in Cursos monográficos de la AIDCI, Vol. VI (Havana, 1957), at 46-47). This diversity of doctrinal conceptions has clear methodological, terminological, and even substantive consequences. Methodologically, each conception gives rise to a different degree of interdisciplinary relationship between private international law and the subject at hand. Terminologically, advocates of including the latter in private international law prefer to speak of conflicts of jurisdiction (thus, in Anglo-Saxon terminology, the "conflict of laws" comprises "the choice of law and the choice of jurisdiction"); in contrast, those who defend an independent conception of the subject include it in what they call "international procedural law", although, naturally, there are exceptions in each current in favour of the prevailing terminology of the other (in the Spanish doctrine, Trías de Bés speaks of "conflictos de competencia judicial" (conflicts of jurisdiction) whilst Miaja de la Muela uses the generic term "Derecho procesal internacional" (international procedural law)). Finally, variants can also be found in the substantive content. In general, the following are recognized as core matters: the determination of the rules of international jurisdiction (cf. infra, No. 5), the law regulating the process, and the enforcement of foreign judgments (although at least one Anglo-Saxon author, Graveson, excludes "the recognition of judgments of foreign courts" from the "choice of jurisdiction"). 
between legislative and jurisdictional conflicts, is clear. Although a detailed examination of the new perspectives arising from this viewpoint falls beyond the scope of this essay, the fact is that the attention being given to the latter form of conflicts is gradually increasing. In this regard, whilst the comparative method has been, in our view, firmly and definitively established in the context of conflicts of laws, in the context of conflicts of jurisdiction - or international procedural law - it has proved essential to enabling a scholarly examination of the matter; hence, the urgent need for a comparative overview of the various national positive law systems prior to attempting such an examination.

This essay, of a very modest scope due to the imposed brevity, will attempt to present a synthetic overview of the principles of international jurisdiction in Spanish law, "locating" them within the framework of comparative law already outlined in the scholarly literature. As relatively little has been written on this matter, ${ }^{3}$ the interest of the present essay is heightened by the propitious situation arising from recent ad boc case law, generally as scarce as it is ambiguous in this area of private international law. ${ }^{4}$

\section{Fundamental preliminary concepts}

2. In what terms is the problem of international jurisdiction generally posed?

By analogy, first, with conflicts of laws, one could say that the problem primarily consists of the specification of the rules of domestic procedural law in the matter of disputes over multinational situations or relations. ${ }^{5}$ In other words, whilst in conflicts of laws the central question is which system

Others also include as core issues the study of the procedural status of foreign nationals, international procedural assistance law, etc.

For the purposes of this essay, it is sufficient to take as a generic starting point the close and undeniable functional connection between conflicts of laws and conflicts of jurisdiction and to note how, in any case, the specific topic at hand the determination of the rules of international jurisdiction - is regarded as a primary matter of the latter or, if one prefers, of "international procedural law".

3 Aside from the attention given to the issue in general works on procedural law and private international law, the literature specifically dealing with the topic is quite scarce. See: W. Goldschmidt, "Problemas de competencia en el Derecho Internacional Procesal de España”, in Mélanges Streit (Pyrsos, Athens, 1939) 429-443; P. Fernández Viagas, "Cuestiones de competencia interjurisdiccional entre tribunales de distinta nacionalidad”, Revista de Derecho Procesal (1958) 325-334; J. M. Trías de Bés, "Las reglas de «competencia general»: ensayo de Derecho procesal internacional español”, Revista jurídica de Cataluña (1960) 7-19.

4 Cf. J. M. Manresa y Navarro, Comentarios a la Ley de Enjuiciamiento Civil, $7^{\text {th }}$ ed., Vol. I (Instituto Editorial Reus, Madrid, 1955), especially at 226-260 and 418-423; and M. Fenech, Doctrina procesal civil del Tribunal Supremo, Vol. I (Aguilar, Madrid, 1956), especially at 558-609 and 1909-1910.

5 The terminological ambiguity between the concepts of jurisdiction and competence is reproduced in the field of international procedural law. In principle, the term jurisdiction is understood to refer to the special right and duty of the state to administer justice (Guasp), i.e. the jurisdictional power of the state as a whole and, at the same time and appropriately attributed, of each specific branch in which it is manifested (ordinary or civil jurisdiction, administrative jurisdiction, military jurisdiction, etc.). In contrast, the notion of competence refers to the specific power of each homogeneous group of courts, i.e. in an objective sense, to the set of matters and procedures over which the court or tribunal can exercise its jurisdiction in accordance with the law (Gómez Orbaneja). In the context of international procedural law, the power of domestic courts to hear disputes over international situations or relations is referred to interchangeably with the terms jurisdiction (jurisdicción, giurisdizione), jurisdictional competence (competencia jurisdiccional, compétence juridictionnelle, competenza giurisdizionale), general competence (competencia general, compétence générale, abstrakte Zuständigkeit), international competence (competencia internacional, compétence internationale, internationale Zuständigkeit), 
of rules should determine the substantive law applicable to extra-, multi-, or international situations, in conflicts of jurisdictions, the core issue is: what rules - and how and with what scope- regulate the jurisdictional function applicable to such situations or relations in the various domestic legal systems?

Of course, the parallelism of the approaches to legislative and jurisdictional conflicts breaks down in many places. Although a detailed description of the differences would exceed the scope of this essay, it should be stressed that they are especially sharp with regard to the methods used to solve or respond to each one. Conflicts of laws are usually solved by means of a system of rules (conflict rules or indirect rules) that determine the law applicable to the situation or relationship at issue based on a connection criterion that can lead equally to the application of substantive rules of the forum or to the application of substantive rules of a foreign legal system. In contrast, in conflicts of jurisdiction, international jurisdiction is determined by each national system according to a set of rules that can only result in the acceptance or declination of the jurisdiction of the forum to hear the various potential extra-, multi- or international disputes. In other words, whilst rules of conflict delimit the various legislative jurisdictions virtually involved in the dispute (Betti), rules of international jurisdiction merely delimit the territorial scope of the forum's jurisdiction, such that each domestic system of rules of international jurisdiction "ne règle pas le sort des matières qu'elle ne s'attribue pas, leur objet étant de fixer la compétence des tribunaux (nationaux) dans les matières où, en raison d'un élément étranger, plusieurs rattachements s'offrent: elles constituent une délimitation du champ d'application de la loi (interne) de compétence vis-à-vis des éléments étrangers qui peuvent tomber sous le cou de ses dispositions". ${ }^{6}$

The explanations given for this scope of the rules of international jurisdiction -limited to the jurisdiction itself- are manifold, but ultimately they are all based on a common argument, namely, that, due to their very sovereign nature, each jurisdiction is free to determine its own jurisdictional scope. At the same time, however, "il résulte de la souveraineté et de l'égalité des Etats dans l'ordre international que chaque Etat est exclusivement compétent pour entreprendre ou permettre des actes de pouvoir sur son territoire, ainsi que pour annuler ou modifier ces mêmes actes. Les actes de pouvoir émanent de la souveraineté des Etats et les juridictions étrangères ne peuvent intervenir".

The idea of conflicts of sovereignty - definitively abandoned in the scholarly dialectics of the conflict of laws - retains its full importance in the doctrinal explanation of conflicts of jurisdiction, leading to its most logical and direct consequence: the exclusive admission of unilateral rules in the context of so-called conflicts of jurisdiction.

3. From what has been said thus far, and strictly with regard to the question of the rules of

etc. In the author's view, this terminological issue can be resolved by clearly defining the meaning of the term one prefers to use. The present paper will use the term international jurisdiction, understood as the jurisdictional ability of the courts of the forum to hear disputes concerning international situations or relations. As will be seen below, the rules governing this ability can take the form of delimited rules of domestic jurisdiction in genere in relation to foreign jurisdictions or be expressed in specific rules of jurisdiction sensu stricto.

6 H. Batiffol, Traité élémentaire de droit international privé, $3^{\text {rd }}$ ed. (Paris, 1959), at 749.

7 N. Fragistas, "La compétence internationale en droit privé", I04 Recueil des cours de l'Académie de Droit International de la Haye (196I-III), at I70-I7I. 
international jurisdiction, three main preliminary conclusions can be drawn:

$\mathrm{I}^{\text {st }}$. In principle, the rules of international jurisdiction are totally independent of the rules of conflict.

$2^{\text {nd }}$. Except where otherwise established by the very few rules of general international law or international agreements, each state is free to determine, according to whatever criteria it deems most appropriate, the scope of its jurisdiction to hear disputes over international situations or relations within its territorial jurisdiction.

$3^{\text {rd }}$. Consequently, unlike in conflicts of laws, domestic rules on international jurisdiction cannot declare a foreign jurisdiction applicable, at least not in a binding sense. Therefore, an exception to international jurisdiction may only be expressed if a court declines jurisdiction ex officio; it cannot, strictly speaking, be ordered to do so ex parte.

$4^{\text {th }}$. Again strictly with regard to the rules governing international jurisdiction, any study of the various positive law systems clearly must begin with the principles of the exclusive and unilateral nature of such rules. However, a comparative analysis shows that various Western legal systems can be grouped into certain standard types of systems that share common features and guiding principles. For the purposes of the present essay, a brief description of these standard types of systems would be helpful in order to determine where the Spanish model falls in the comparative legal context.

\section{THE DIFFERENT SYSTEMS OF INTERNATIONAL JURISDICTION IN THE CONTEXT OF WESTERN LEGAL SYSTEMS}

5. Various criteria have been proposed to classify these systems. Miaja de la Muela has generically distinguished between Continental and Anglo-Saxon legal systems. ${ }^{8}$ Fragistas recently further subdivided the former group, yielding a total of four types of systems: Latin, Germanic, AngloAmerican and Swiss. ${ }^{9}$

Setting aside, for the time being, the latter two - whose respective singularities are explained, in the case of the former, by the traditional particularism with which Anglo-Saxon countries think about and apply the law, and, in the Swiss case, by the interference of cantonal law- here we will briefly review the defining particularities of the first two.

The most salient feature of the Latin system, exemplified by the French system, is its use of the nationality of the parties as the criterion to determine international jurisdiction. A forum thus has jurisdiction provided one of the parties - plaintiff or respondent - is a national of the corresponding country. ${ }^{10}$ In contrast, the Germanic system settles matters of international jurisdiction by directly applying the rules of domestic territorial jurisdiction, which "implique que la compétence internationale est la résultante des compétences territoriales internes". ${ }^{\text {II }}$

\footnotetext{
8 A. Miaja de la Muela, Derecho internacional privado, II, $2^{\text {nd }}$ ed. (Madrid, 1956), at $4 \mathrm{I} 4$.

9 Fragistas, supra n. 7, at 205 et seq. On the terms of this problem in the Soviet positive system, see the interesting study by L. García Arias "El sistema de Derecho Internacional Privado de la Unión Soviética”, I2 TEMIS Revista de la Facultad de Derecho de Zaragoza (1962), especially at 29 et seq.

1o French, Italian and Greek systems (Cf. Fragistas, supra n. 7, at 205).

II Fragistas, supra n. 7, at 2I2. German, Austrian and Portuguese systems.
} 
A narrower comparison of only the most generic features of these two systems reveals very different approaches in their respective criteria. In using the foreign nationality of one of the parties as the basis for international jurisdiction, the Latin system approaches the question in terms of private international law. Thus, the determination of international jurisdiction ratione personae works as a spatial delimitation of the state's jurisdiction with regard to foreign jurisdictions. ${ }^{\mathrm{I2}}$ In contrast, the Germanic system approaches the problem of international jurisdiction in terms of domestic law, which can be interpreted, at least at first glance, as an application of the principle of equal treatment of nationals and foreigners in that context. ${ }^{\mathrm{I3}}$

A detailed examination of the specific forms of each of these systems shows that these general criteria undergo appreciable changes in actual practice. In Latin systems, case law has clearly evolved towards the application of the rules of domestic territorial jurisdiction. ${ }^{14}$ In Germanic systems, the application of special jurisdictions extends the territorial jurisdiction of domestic courts to the detriment of persons domiciled abroad, which ultimately entails discrimination against nonnationals. ${ }^{15}$

Although it is not possible to explore these comparative observations in greater depth here, it should be underscored that, as a result of this dual convergent trend in actual practice at the legislative and, especially, jurisprudential level, the differences between the two systems have grown less stark. In this regard, there is now a widespread tendency to transpose the rules of domestic territorial jurisdiction to the context of international jurisdiction. ${ }^{16}$

\section{THE RULES OF INTERNATIONAL JURISDICTION IN THE SPANISH LEGAL SYSTEM}

6. As in the case of conflicts of laws, in the case of conflicts of jurisdictions, the positive regulations contained in Spanish law are insufficient and ambiguous. Nor has case law completely filled the "existing gaps", and its interpretation of legal texts has often been contradictory. This combination of factors may explain why the scholarly literature - both the strictly proceduralist and the strictly internationalist- has yet to formulate a unanimous opinion on the principles and rules that determine international jurisdiction in Spanish law. ${ }^{17}$

${ }^{\mathrm{I} 2}$ For a current rethinking of private international law ratione personae, see M. Jezdic, "L'élément étranger et l'étendue du droit international privé", in De Conflictu Legum, supra n. I, at 268 et seq.

i3 This general criterion is also the one applied in the Soviet positive system (see García Arias, supra No. 9, at 29).

${ }^{14}$ Signs of this phenomenon can be seen in the French system (see Batiffol, Observations sur les liens, supra n. I, at 268); in contrast, the Italian system continues in the traditional vein (see E. Redenti, Diritto Processuale Civile, Vol. I (Milan, I952), at 152 ).

is For example, by means of the jurisdiction of the property (Gerichtsstand des Vermögens) or of the place of invoice (Gerichtsstand der Faktura) (see E. von Riezler, Internationales Zivilprozessrecht (Berlin-Tübingen, 1949), at 219 et seq.).

${ }_{16}$ The Anglo-Saxon system (cf., for example, Ehrenzweig, Conflict of Laws (St. Paul, 1959), especially at 91 et seq.) and Swiss system (Cf. Guldener, Das internationale und interkantonale Zivilprozessrecht der Schweiz (I95I), especially at 37 et seq.) have undergone a similar evolution.

${ }_{17}$ The following is the list of the general and monographic works that have addressed the issue at hand. Hereinafter, they will be cited solely by the author. I) Proceduralist doctrine: J. Guasp, Comentarios a la Ley de Enjuiciamiento civil, Vol. I (Madrid, 1943), $2^{\text {nd }}$ edition (Madrid, 1948); J. Guasp, Derecho procesal civil (Madrid, 1956); E. Gómez Orbaneja and V. Herce Quemada, Derecho procesal, Vol. I, Derecho procesal civil (Madrid, 1955); L. Prieto Castro, Derecho procesal civil, Vol. I; J. M. 
The present study aims to present certain overall conclusions based on the data available on these three dimensions - positive law, case law and scholarly literature- in the most recent examples thereof.

7. Under current Spanish procedural law, international jurisdiction is regulated by two main texts: Articles $5 \mathrm{I}$ and 70 of the Civil Procedure Law of $188 \mathrm{I}$ [hereinafter, LECiv from the Spanish]. Under the former:

"The ordinary courts shall be the only ones competent to hear civil actions arising in Spanish territory between Spaniards, between foreigners, or between Spaniards and foreigners."

Article 70, referring to Articles 56 to 69, which determine the jurisdiction of the Spanish courts, provides:

"The foregoing provisions regarding jurisdiction shall include foreigners who petition the Spanish courts for matters of non-contentious jurisdiction, intervene in them, or appear in court as plaintiffs or defendants, against Spaniards or other foreigners, when the Spanish courts are competent to hear such matters according to the laws of the Kingdom or to treaties with other powers." ${ }^{18}$

All problems concerning international jurisdiction in the Spanish system are related to the significance and scope of these provisions. However, since neither the scholarly literature nor case law have produced a uniform interpretation, attention should be called to the specific issues that must be addressed with regard them both. Formulated as questions, they are as follows:

Manresa, Comentarios, Vol. I, supra No. 4; P. Aragoneses, "Problemas del proceso civil con elementos extranjeros”, 2 Revista de Derecho Procesal (196I), at I25 et seq.; P. Fernández Viagas, Cuestiones de competencia interjurisdiccional, supra n. 3; M. de la Plaza, "Excepciones procesales con carácter internacional", XXIX Revista de Derecho Privado (1945), at 673 et seq.; U. Ruiz Gutiérrez, "La competencia de los tribunales españoles en actos en que intervienen elementos extranjeros, con referencia a los de jurisdicción voluntaria” I Revista de Derecho Procesal (1962) at 9 et seq. II) Private international law doctrine: J. M. Trías de Bés, Derecho Internacional Privado. Sistema del Derecho español positivo (Barcelona, 1932); A. Miaja de la Muela, supra No. 8; W. Goldschmidt, Sistema y filosofía del Derecho internacional privado, $2^{\text {nd }}$ ed. (Buenos Aires, 1952-1954), especially Vol. III; J. G. Verplaetse, Derecho internacional privado (Madrid, 1954); W. Goldschmidt, Problemas de competencia, supra n. 3; A. Luna García and J. Hernández Canut, "Dictámenes sobre competencia de los Tribunales españoles en juicio de alimentos provisionales entre extranjeros”, Anuario de Derecho Civil (195I), at 1527 and et seq.; J. M. Trías de Bés, Las reglas..., supra n. 3 .

18 Prior to the LECiv of 1855 , the matter was regulated by the Royal Decree of 17 November 1852 , on alienage [hereinafter, RDExtr., from the Spanish], specifically by Arts. 29, 32 and 33 thereof, which provided as follows: Art. 29: "Resident and non-resident foreigners are subject to the laws of Spain and to the Spanish courts for any crimes they may commit in Spanish territory and for the fulfilment of any obligations they may undertake in or outside Spain, provided they are in favour of Spanish subjects."; Art. 32: "Resident and non-resident foreigners are entitled to the administration of justice by the Spanish courts in accordance with the laws in any actions they may bring for the fulfilment of obligations undertaken in Spain or that should be met in Spain or concerning assets located in Spanish territory."; Art. 33: "In business matters between foreigners or against foreigners, even if they are not the result of real action or of personal action due to obligations undertaken in Spain, Spanish judges shall nevertheless be competent when the aim is to prevent fraud or adopt urgent and provisional measures...". As the LECiv of December 1855 contained no provisions on the matter, it can be properly understood to have left the rules of the RDExtr. in force (in this regard, see: Manresa, at 217; Ruíz Gutiérrez, at I3). Of course, the question of the current validity of the provisions of the RDExtr. is, in view of the aforementioned Arts. 5I and 70 of the current LECiv of I88I, one of the most controversial fundamental problems. To this end, it must be recalled that, between the LECiv of 1855 and the current one, two legal texts were enacted affecting matters of jurisdiction and competence as a whole: the Decree on Unification of Jurisdictions of 6 December 1868 and the Organic Law on Judicial Power of 1870 [hereinafter, LOPJ from the Spanish]. Art. I of the Decree and Art. 267 of the LOPJ were included "with slight modifications, affecting the wording more than the concept" (Manresa, at 227, translated from the Spanish) in Art. 5I of the LECiv of I88I in force today. Similarly, the current Art. 70 coincides with Art. 319 LOPJ. 
- What is the meaning of Article 5I within the Spanish procedural system in relation to the matter of international jurisdiction?

- What is the significance of the relationship between said Article 5I and Article 70 of the same legal text?

- With regard to Article 70, how should the formula "when the Spanish courts are competent to hear such matters according to the laws of the Kingdom" be interpreted?

8. As we have repeatedly stated, the case law has not established a clear, univocal doctrine in this matter. With regard to the outline of the generally recognized fundamental principles, ${ }^{19}$ the Spanish Supreme Court [hereinafter, TS] has adopted the following position:

$\mathrm{I}^{\text {st }}$. Recognition of the existing independence between the rules governing conflicts of laws and the regulations applicable to matters of international jurisdiction. ${ }^{20}$

$2^{\text {nd }}$. Emphatic affirmation of the sovereign power of the Spanish legal system to delimit the scope of its jurisdiction within the scope of its territorial jurisdiction. ${ }^{21}$ This principle has been expressed in some judgments as the absolute and unlimited jurisdiction of the Spanish courts to hear all types of actions brought before them "except where otherwise agreed in an international treaty" ${ }^{22}$ and has been positively based on Article 5I LECiv. ${ }^{23}$ A direct consequence of this conception has been the nonacceptance of submission to a foreign court to the detriment of a Spanish one. ${ }^{24}$ In other judgments, however, this absolute formulation has been less rigorous. ${ }^{25}$

$3^{\text {rd }}$. In general, the TS has recognized the exclusive unilateral scope of its rules of international jurisdiction. ${ }^{26}$

The interpretation of the positive rules potentially applicable to problems of international jurisdiction has been much less consistent in case law.

With regard to the meaning and scope of Article 5I LECiv, and in keeping with the interpretation thereof in the aforementioned judgments, the TS has, on several occasions, considered it an exclusive

19 Cf. supra, at 6-7 [sic].

${ }_{20}$ This distinction is clearly contained in the judgments of Io October 1901, Io February 1915 and 27 January 1933. It is also noted, albeit less clearly, in the judgment of I June 1929. A recent judgment, that of 22 February 1960, exceptionally diverged from this correct interpretation of the nature of the rules of international jurisdiction, basing the jurisdiction of the Spanish courts on Art. I0.2 of the Spanish Civil Code, a provision which, of course, refers to conflicts of laws and in no way to conflicts of jurisdiction (see the criticism of this judgment in Aragoneses, at I40, and Ruiz Gutiérrez, at 25).

${ }_{21}$ Unanimously and expressly ratified in all the decisions affecting these matters (most recently in the judgment of 30 May 196I).

${ }_{22}$ The judgment of 28 November 1928 affirmed the "attractive nature" of Spanish jurisdiction; likewise, the judgments of Io February 1915, 3I January 1921, I6 December 1927, I June 192I and 2I February 1935. The judgment of 27 February 1933 based the jurisdiction of the Spanish courts in matters of divorce between an Italian and a Spaniard on the grounds of "public necessity".

${ }_{23}$ Judgments of I2 May I886 (referring to Art. 267 LOPJ, whose content is analogous to that of Art. 5I LECiv), I3 October 1890 and those cited in the previous note.

24 Judgment of 20 November 1894 . The judgment of 17 January 1912 held that "because the appellant has the status of Spaniard, he may not invoke the jurisdiction of foreign courts" (translated from the Spanish).

${ }_{25}$ The sentences of 28 October I92I and 3 May 1929 expressly declare the lack of jurisdiction of the Spanish courts. Those of ro December 1906 and I June 1924 point to the possibility of submission to foreign courts.

${ }_{26}$ The judgment of 22 February 1960 is also an exception in this regard, insofar as the operative part of the judgment declares the Bolivian jurisdiction competent. 
general principle in the matter, ${ }^{27}$ although in other decisions it has related it to Article 70 LECiv. ${ }^{28}$

The jurisprudential solutions regarding the interpretative problems posed by Article 70 LECiv are even more ambiguous and contradictory. Does this provision entail the pure and simple application of the rules of domestic jurisdiction to matters of international jurisdiction? Should the formula "when the Spanish courts are competent to hear such matters according to the laws of the Kingdom" be understood to leave Articles 29, 32 and 33 RDExtr. in force? In that case, are they the "laws of the Kingdom" to be used to resolve such issues?

The continued validity of the provisions of the RDExtr. has been affirmed in some judgments; ${ }^{29}$ others have questioned $i t ;^{30}$ and some TS decisions have resolved the question of international jurisdiction without taking the existence of these provisions into account at all, affirmatively or negatively. ${ }^{3 \mathrm{I}}$

Equally varied interpretations have been given to Article 70: whilst various judgments have held that it applies in cases of international jurisdiction, ${ }^{32}$ others have categorially denied it. ${ }^{33}$

Finally, on two occasions, the TS has established the principle of reciprocity as a general rule in the matter. ${ }^{34}$

9. The contradictory nature of the various solutions adopted in the case law is clear. To wit:

(a) in some cases, the TS has located the rules governing international jurisdiction in Articles 29, 32 and 33 RDExtr.;

(b) other times, the case law has asserted the absolute, unlimited nature of Spanish jurisdiction within the scope of its territorial jurisdiction based on an extreme interpretation of Article 5I LECiv;

(c) a large number of judgments have settled the corresponding questions of international jurisdiction through direct application of the rules of domestic territorial jurisdiction;

(d) twice, the principle of reciprocity has been cited as a decisive criterion in the matter; and

(e) in one (quite recent) case, the TS used a rule of conflict to settle an issue of international jurisdiction.

Io. The lack of unequivocal positive regulations coupled with this jurisprudential shape-shifting have also given rise to divergent theses at the theoretical level.

Leaving aside solutions (b), (d) and (e), which have been unanimously rejected in the literature based on wholly incontrovertible reasonings, 35 one finds that the controversy has arisen between those

27 See the judgments cited supra nn. 23 and 22.

28 Judgments of 3I January 1921, Io June 1933 and 30 May 196r.

29 Categorically in the judgment of 13 June 1917. It can also be inferred from the judgments of 15 November 1898 and 17 October I90I.

30 In the judgment of io February 1915.

31 Judgments cited supra n. 23, and infra n. 32.

32 Judgments of I July I897, I7 January 1912, I3 June 1917, I0 June 1933 and 30 May 1961.

33 Judgments of Io February 1915, 3I January I92I and I June 1929.

34 As a sole criterion in the judgment of Io February 1915; cumulatively in that of 27 January 1933.

35 Against the solution in the judgment of 22 February 1960, expressly: Aragoneses, at 140-I4I, and Ruiz Gutiérrez, at 25. The criterion of reciprocity is ruled out even from a de iure condendo perspective (Guasp, Comentarios..., $2^{\text {nd }}$ ed., at 285 ), as this thesis is considered to have been "doctrinally surpassed" (Ruiz Gutiérrez, 26). The interpretation of Art. 5I LECiv in the sense of solution b) is unanimously rejected by both the proceduralist and internationalist literature; the article simply declares the exclusivity of the ordinary jurisdiction or, in other words, the principle of the territoriality of Spanish 
who defend the continued validity of Articles 29, 32 and 33 RDExtr. and those who, understanding those articles to have been repealed, advocate the application of the rules of domestic territorial jurisdiction in cases of international jurisdiction.

The continued validity of the provisions of RDExtr. has been based: I) on the lack of any express provision on the matter; 2) on the logical interpretation imposed by the wording of Article 70 LECiv; and 3) on the existence of confirmatory case law. Thus, under this thesis, in Spanish law, international jurisdiction is governed by Articles 29, 32 and 33 RDExtr., which ultimately places the Spanish system within the generic framework of the Latin system. ${ }^{36}$

In contrast, a majority of scholars considers those articles of the RDExtr. to have been repealed, whether as a result of the Decree on Unification of Jurisdictions, ${ }^{37}$ Article 5I LECiv itself -in relation to Art. 2.182 of the same legal text ${ }^{38}$ - or Article 27 of the Spanish Civil Code. ${ }^{39}$ Consequently, questions of international jurisdiction should be resolved by applying the provisions governing domestic territorial jurisdiction. ${ }^{40}$ This interpretation therefore places the Spanish system in the generic line of the Germanic system.

\section{CONCLUSIONS}

II. A joint assessment of the data obtained at all three levels - positive law, case law and the literature- points, above all, to the impossibility of formulating a conclusive solution in absolute terms. The two scholarly theses considered here - given the doctrinal unviability of the other solutions the TS has adopted in different cases- are based on arguments that, although suitable, are in neither case definitive. The existing gaps in the positive regulations and, even more importantly, the jurisprudential contradictions (which make it possible to "skew" the doctrine of the TS in either of the chosen directions) render pure hermeneutic reasoning, limited strictly to the texts, insufficient. This is even more true with regard to the testimony to the fundamentals of positive law made by an ambiguous, when not outright contradictory, case law.

Based on these perspectives, we are inclined to formulate a response based on the guiding principles of jurisprudential practice and, more specifically, on the outcomes sought by this practice. In this regard, as noted, the Spanish courts have clearly favoured a maximalist interpretation of the

procedural law "regardless of the nationality of the parties or the law of the derived right" (Gómez Orbaneja, at 34, translated from the Spanish).

36 Proceduralists who maintain this thesis include Manresa, at 227; Prieto Castro, at 84; Fenech, at 559; and Fernández Viagas, at 329, amongst others. It was also the initial stance taken by Guasp (Comentarios..., $\mathrm{I}^{\text {st }}$ ed., at 289 et seq.; $2^{\text {nd }}$ ed., at 282 et seq.) until the first edition of Derecho procesal civil (1956, at 197). Internationalists include Trías de Bes (Derecho internacional privado, at 117 , and Las reglas..., supra n. 3, at 9-10) and Luna and Hernández Canut, at 1530.

37 In this regard, see Miaja de la Muela, at 420.

${ }_{38}$ Thus, Plaza, at 673; Goldschmidt, III, at 63. With reservations, Ruiz Gutiérrez, at 17-I8. Against: Fernández Viagas, 328; Trías, Las reglas..., at 9; and Luna and Hernández Canut, at 1529.

39 Art. 27 of the Civil Code provides: "Foreigners in Spain have the same civil rights as Spaniards, except as provided in special laws and in treaties." This thesis is championed by: Guasp, Derecho procesal civil, at II8; Aragoneses, at I42; Goldschmidt, III, at 63; Ruiz Gutiérrez, at 27 et seq. Against: Fernández Viagas, 328; Luna and Hernández Canut, at 1530.

40 This conclusion is obtained directly, from a strict interpretation of Art. 70 in relation to Art. 51, or derivatively, as a result of Art. 27 of the Civil Code (in the latter regard, see especially: Guasp and Ruiz Gutiérrez). 
virtual nature of Spanish jurisdiction in cases of international jurisdiction. In any case, the chosen basis of positive law has tended to serve that purpose..$^{4 r}$

Under these conditions, a realistic interpretation of the system effectively applied in the Spanish legal system fits with the thesis that holds that Articles 29, 32 and 33 RDExtr. remain in force, a thesis that requires an extensive interpretation of those provisions. ${ }^{42}$ On the other hand, the opposite thesis seems more appropriate: in fact, the practice followed by the Spanish courts could be said to reflect, in general, the criteria followed by the Germanic systems, i.e. the application of the rules of domestic territorial jurisdiction in cases of international jurisdiction. However, as in those systems, this does not result in clearly equal treatment of nationals and foreigners. ${ }^{43}$ In this regard, Spanish practice has expanded domicile to the detriment of those domiciled abroad (through Article 69.2 LECiv) and has also established the jurisdiction of the property with regard to companies with branches or representation in Spain (Article Is of the Commercial Code in relation to Article 65.2 LECiv).

The trend marked by the recent judgment of 30 May 1961 - which resolved a case of international jurisdiction by designating the rules of domestic territorial jurisdiction as applicable to it "in accordance with Art. 70 LECiv" - could be the first step towards an unequivocal jurisprudential confirmation of a system of rules of international jurisdiction that the predominant line of Spanish practice has in fact already been following. ${ }^{44}$

${ }_{41}$ Cf. the judgments cited supra nn. 22, 23, 24 and 25.

${ }_{42}$ Cf. Guasp (Comentarios..., , ${ }^{\text {st }}$ ed., at 29I). Trías (Aragoneses, at I42, No. I8). The generic feature of the Latin system, literally reflected in the provisions of the RDExtr., is lost by dint of exceptions.

${ }^{43}$ Cf. Miaja, II, at 4IO; Verplaetes, at 644. That is why, in the author's view, basing the system on Art. 27 of the Civil Code is "premature".

44 In this regard, it should be noted that in all cases in which Spanish jurisdiction has been declared competent in accordance with the provisions of the RDExtr., the application of the rules of territorial jurisdiction would have produced the same outcome. This predominant line also bears witness to the jurisprudential acceptance of submission to the Spanish courts to the detriment of foreign ones "without conditions or restrictions". 